\title{
THE MARRIOTT CELL: A CONVERSATION WITH MOHAMED FAHMY
}

\author{
November 29, 2016
}

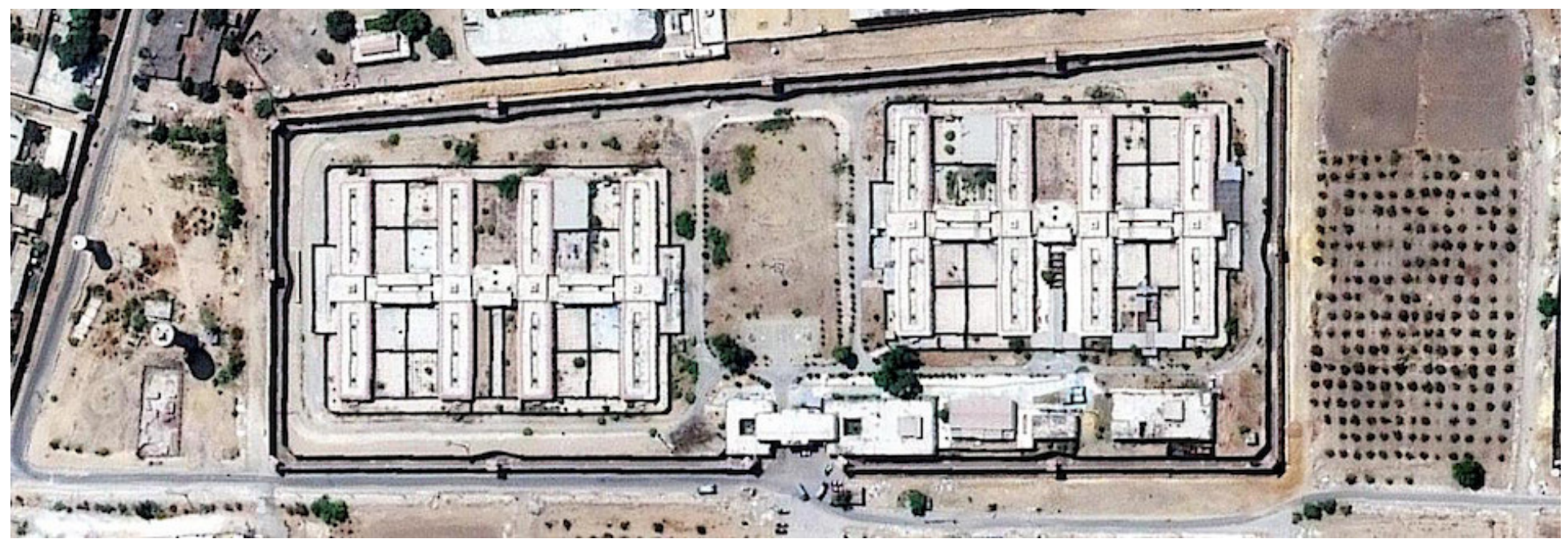

MOHAMED FAHMY \& ADEL ISKANDAR

\section{TUESDAY, NOVEMBER 29, 7:00PM-9:00PM, ROOM 1900, SFU HARBOUR CENTRE}

Co-sponsored by SFU's Institute for the Humanities, Global Communication MA Double Degree, School of Communication, Centre for Comparative Study of Muslim Societies and Cultures (CCSMSC), School of International Studies (SIS), and The Media Democracy Project.

Award-winning journalist Mohamed Fahmy presents his widely anticipated new book, The Marriot Cell, which offers an in-depth account of his wrongful incarceration in Cairo's maximumsecurity Scorpion Prison for terrorists and political leaders, and his subsequent battle for justice. An important book that reads like a political thriller, The Marriot Cell is a testament to the critical importance of journalismtoday; an inspiring love story that made front-page news; and a profoundly personal drama of one man's fight for freedom.

On the night of December 29, 2013, Egyptian security forces, in a dramatic raid on the Marriott Hotel, seized Fahmy (Canadian-Egyptian Bureau Chief for Al Jazeera English) and two of his colleagues, Peter Greste and Baher Mohamed, accusing them of fabricating news as members of the outlawed Muslim Brotherhood.

Their trials became a global cause célèbre condemned as a travesty. But Fahmy also never stopped being a journalist: inside Scorpion he found himself cheek by jowl with notorious Muslim Brotherhood leaders, Al Qaeda fighters, and ISIS sympathizers. Always intrepid, he took advantage of the situation to "interview" the Brotherhood about their aims, gaining exclusive insight into the geopolitical feuds between Egypt, Saudi Arabia, and the UAE on one hand and Qatar and its allies, including Turkey on the other-interviews that led him to sue his former employer, Al Jazeera, from prison. The complex power brokering of Middle Eastern and Western governments left three men trapped in a web he describes as "Global McCarthyism."

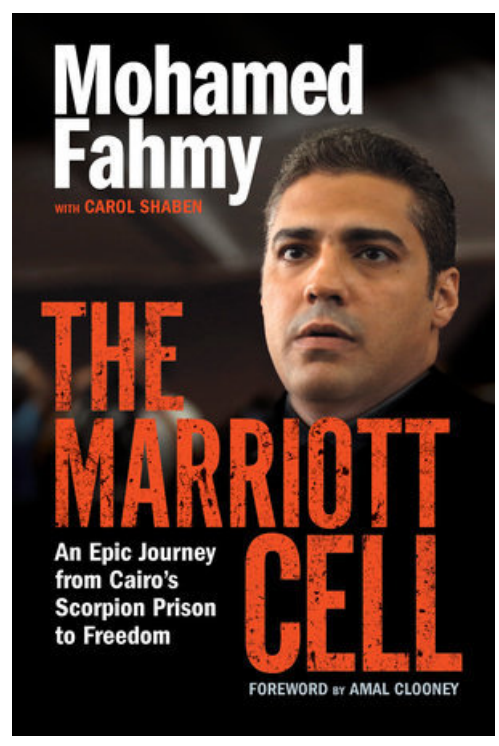


In this exclusive unrestricted conversation, Simon Fraser University's Adel Iskandar engages Fahmy on a wide range of critical issues including revolution, incarceration, Al-Jazeera, Islamist politics, and press freedoms.

SPEAKERS

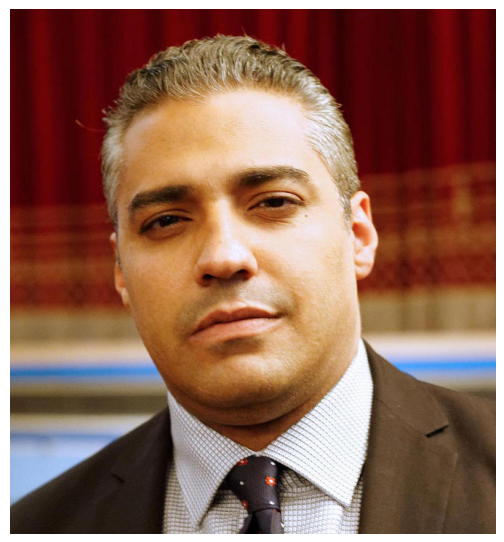

Mohamed Fahmy, a dual Canadian-Egyptian award-winning journalist, war correspondent, and author entered Iraq on the first day of the war in 2003 with the Los Angeles Times. He has reported extensively on the Middle East and North Africa. In 2012 he was among the CNN team honoured with a Peabody Award for the network's coverage of the Arab Spring. In the same year he won the Tom Renner Investigative Reporting Award for producing the CNN Freedom Project documentary series Death in the Desert, which exposed the trafficking of Sub-Sahara Africans to Israel through Sinai-Egypt. He was appointed Al Jazeera English Egypt bureau chief in September 2013. He is the recipient of the Canadian Committee for World Press Freedom Award from (UNESCO). He and his wife Marwa Omara, founded the Fahmy Foundation NGO in 2015 to provide financial assistance and advocate on behalf of imprisoned journalists and prisoners of conscience worldwide. Upon returning to Canada he joined the University of British Columbia as an adjunct professor. His book titled The Marriott Cell is out in Canadian bookstores on November 15 th.

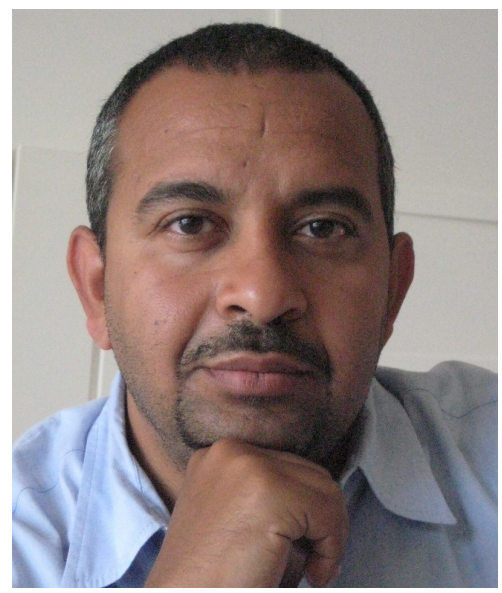

Adel Iskandar is an Assistant Professor of Global Communication at Simon Fraser University. He is the author, co-author, and editor of several works including "Egypt In Flux: Essays on an Unfinished Revolution" (AUCP/OUP); "Al-Jazeera: The Story of the Network that is Rattling Governments and Redefining Modern Journalism" (Basic Books); "Edward Said: A Legacy of Emancipation and Representation" (University of California Press); "Mediating the Arab Uprisings" (Tadween Publishing), and Media Evolution on the Eve of the Arab Spring" (Palgrave Macmillan). Iskandar's work deals with media, identity and politics; and he has lectured extensively on these topics at universities in more than thirty countries. His forthcoming works deal with propaganda and cultural dissidence online. Prior to his arrival at SFU, Iskandar taught for several years at the Center for Contemporary Arab Studies and the Communication, Culture, and Technology Program at Georgetown University, in Washington, DC. He is a co-editor of the online publication Jadaliyya. 